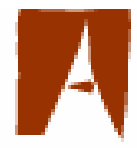

Universitat Autònoma de Barcelona

Documents de Treball

ENTREPRENEURSHIP, MANAGEMENT

SERVICES AND ECONOMIC GROWTH

Vicente Salas Fumás

J. Javier Sánchez Asín

Document de Treball núm. 06/1

Departament d'Economia de l'Empresa 
(C) Vicente Salas Fumás, J. Javier Sánchez Asín

Coordinador / Coordinator Documents de treball:

David Urbano

http://selene.uab.es/dep-economia-empresa/recerca/Documents.htm e-mail: david.urbano@uab.es

Telèfon / Phone: +34 935814298

Fax: +34 935812555

Edita / Publisher:

Departament d'Economia de l'Empresa http://selene.uab.es/dep-economia-empresa/

Universitat Autònoma de Barcelona

Facultat de Ciències Econòmiques i Empresarials

Edifici B

08193 Bellaterra (Cerdanyola del Vallès), Spain

Tel. 935811209

Fax 935812555 


\title{
ENTREPRENEURSHIP, MANAGEMENT SERVICES AND ECONOMIC GROWTH
}

\author{
Vicente Salas Fumás \\ J. Javier Sánchez Asín
}

Document de Treball núm. 06/1

La sèrie Documents de treball d'economia de l'empresa presenta els avanços i resultats d'investigacions en curs que han estat presentades i discutides en aquest departament; això no obstant, les opinions són responsabilitat dels autors. El document no pot ser reproduït total ni parcialment sense el consentiment de l'autor/a o autors/res. Dirigir els comentaris i suggerències directament a l'autor/a o autors/res, a la direcció que apareix a la pàgina següent.

A Working Paper in the Documents de treball d'economia de l'empresa series is intended as a mean whereby a faculty researcher's thoughts and findings may be communicated to interested readers for their comments. Nevertheless, the ideas put forwards are responsibility of the author. Accordingly a Working Paper should not be quoted nor the data referred to without the written consent of the author. Please, direct your comments and suggestions to the author, which address shows up in the next page. 



\title{
Entrepreneurship, Management Services and Economic Growth*
}

\author{
Vicente Salas Fumás• \\ J. Javier Sánchez Asín
}

University of Zaragoza

January 2006

\begin{abstract}
We model the joint production of entrepreneurs and workers where the former provide both entrepreneurial (strategic) and managerial (coordination, motivation) services, and management services are shared with individual workers in an output maximizing way. The static equilibrium of the model determines the endogenous share of entrepreneurs in the economy in a given moment of time. The time dynamics of the solution implies that a given growth rate in quality of entrepreneurial services contributes to productivity growth proportionally to the share of entrepreneurs at the start of the period and improvement in quality of entrepreneurial services is convergence enhancing. Model predictions are tested with data from OECD countries in the period 1970-2002. We find that improvements in quality of entrepreneurial services over time explain up to $100 \%$ of observed average productivity growth in these countries.
\end{abstract}

*The authors acknowledge financial support from project SEJ2004-07530-C04-03/ECON. They also thank Martin Larraza and Pere Otín for their comments to a previous version of the paper.

- Corresponding author, Facultad de Económicas, C. Gran Vía 4, 50005, Zaragoza, Spain; vsalas@unizar.es 


\section{Introduction. -}

Although there are many logical arguments that link entrepreneurial activity with economic growth of the nations, and many countries deploy expensive policy actions to foster entrepreneurial initiatives, we are far from convincing theoretical analysis and empirical evidence that supports the thinking and policy initiatives. This paper presents a stylized theoretical model on entrepreneurship and productive efficiency, together with new empirical evidence about the relationship between entrepreneurship and economic growth in OECD country members in the period 1970 to 2002 . We report a positive association between productivity growth of the countries and proportion of entrepreneurs in their working population at the beginning of the period. The strength of this association increases when controlling for difference in productivity level, also at the beginning of the period, and controlling for country individual fixed effects. So, ceteris paribus, productivity growth is higher in countries with larger entrepreneurial base. The evidence can be explained by the fact that countries with a broader base of entrepreneurs benefit relatively more from improvements in quality of entrepreneurial services over time.

Drawing from early papers by Lucas (1978) and Rosen (1982) we model a production process that combines entrepreneurial and direct labor services in an output maximizing way. The model allows for differences in the quality of entrepreneurial services relative to the quality of services from direct workers. Higher quality of entrepreneurial services affects output in two ways, better "strategic" decisions that increase the productivity of the organization as a whole, for example product or process innovations; and better "managerial" decisions that improve efficiency through better coordination and supervision of direct workers. Profit maximization behavior of firms and equilibrium conditions in the supply and demand of labor determine the equilibrium share of entrepreneurs of the economy. The solution to the static economic model provides insights on how to compare entrepreneurship and economic development in a cross section of countries and a given moment of time. Next, we model productivity and productivity growth and show that the two variables can be written as a function of variables related with entrepreneurial capital, such as proportion of entrepreneurs in the labor population, quality of entrepreneurial services and improvements in this quality over time. 
The empirical analysis models productivity growth in OECD countries as a function of start of the period share of entrepreneurs in the country and other control variables. The coefficient of the share of entrepreneurs' variable measures the average rate of improvement across countries in the quality of entrepreneurial services over time. We find that the contribution of relative improvement in quality of entrepreneurial services can explain from $50 \%$ to over $100 \%$, depending upon the model specifications, of the accumulative average rate of GDP growth in the OECD countries along a twenty five years period. This contribution only accounts for the positive effect in total factor productivity growth due to more effective managerial function of the entrepreneurs.

Entrepreneurs perform specialized functions that directly or indirectly must contribute to output and growth, Baumol $(1968,2004)$. The list of entrepreneurial activities reported in the literature includes, innovation and creative destruction, Schumpeter (1934), Acs and Audretsch (1990); new firms creation and resulting increasing competition, Nickel et al (1997), Callejón and Segarra (1999); matching supply and demand, Kirzner (1979); input co-ordination, Coase (1937); monitoring the quality of inputs in team production, Alchian and Demsetz (1972); risk taking, Knight (1921), Kihlstrom and Laffont (1979). But with few exceptions, for example Schmitz (1989), entrepreneurship is not explicitly incorporated into the theoretical models of economic growth, missing the opportunity to get better insights about how to proceed in the empirical analysis ${ }^{1}$.

The model presented in this paper provides an explanation, alternative to spill over effects of Schmitz (1989), to why productivity growth will be positively associated with share of entrepreneurs at the beginning of the period. Second, it provides theoretical foundations for some observed regularities on the relationship between entrepreneurial variables and economic development, for example the negative association between share of entrepreneurs and countries' income per capita reported in some empirical papers, Kuznets (1971), which can not be explained from Schmitz's (1989) formulation. Third, it provides robust empirical evidence that quality in entrepreneurial services can

\footnotetext{
${ }^{1}$ Acs and Storey (2004) provide an overview of recent empirical literature on entrepreneurship and economic development and raise several methodological issues on how research is performed. Their conclusion is that we are far away from a theoretical framework that can support sound empirical analysis on entrepreneurship and economic growth.
} 
be an important source of productivity growth through a more effective "visible hand" role of entrepreneurs in coordinating and motivating other factors of production. The results of the paper suggest that managerial services from entrepreneurs can be a source of economic growth as important as pure entrepreneurial services, even though conventional wisdom in entrepreneurship research gives far more importance to the later than to the former.

The rest of the paper is organized as follows. Section 2 presents the basic theoretical model of the neo-classical firm with entrepreneurial inputs in which entrepreneurs perform two functions, set the strategy and manage the internal workings of firms. Section 3 extends the model to allow for capital inputs and to explain productivity and productivity growth over time. Section 4 revises some of the existing empirical literature on entrepreneurship and growth under the lens of the theoretical results of the paper. Section 5 presents our own empirical analysis that tests the main empirical prediction of the model. Conclusions summarize the main results.

\section{The model of production with entrepreneurial and direct labor inputs.-}

We start with an economy where firms use labor services of two kinds, those supplied by the direct workers and those supplied by the entrepreneurs. The productivity of each direct worker is affected by the time of entrepreneurial input dedicated to coaching, supervising or helping her. Entrepreneurs also take strategic decisions, for example product mix, product and process innovation, that improve the efficiency of the whole organization (non divisible input). We use the assumptions of Rosen (1982) to combine entrepreneurial time and direct workers' effort into an aggregate measure of output from labor services. The model is solved in terms of profit maximizing direct labor and equilibrium mix of entrepreneurial and direct labor services.

There are two types of persons, those that work as direct workers and those that work as entrepreneurs. Quality of labor services provided by entrepreneurs relative to the quality of direct workers is given by $r$ with the implicit assumption that $r$ will be greater or equal to one since more able workers are more productive directing others' persons work. In the short term the number of entrepreneurs of quality $r$ is given and equal to $E$. The value of $r$ can vary across economies and over time and can be interpreted as an aggregate measure of quality of entrepreneurial quality of the economy. The analysis 
ignores possible liquidity and wealth constraints that can limit entrepreneurial activities in a world of asymmetric information and imperfect financial markets, Evans and Jovanovic, (1989), and assumes a world of certainty, so differences in risk aversion across the population, that could affect the supply of entrepreneurs in a scenario of uncertainty, do not alter the main results.

Let $t_{i}$ be the entrepreneurial time dedicated to complement the effort/time of direct worker $i, a_{\mathrm{i}}$. The labor services jointly produced by direct worker $i$ and the entrepreneur she is working with, is given by,

$$
l_{i}=g(r) f\left(r t_{i} ; a_{i}\right) \quad \text { for all } i
$$

Where $f()$ is assumed a linear homogeneous function of inputs $r t_{i}$ and $a_{i}$, increasing with the quantity of inputs and concave; and $g(r)$ is increasing in $r$; Rosen (1982). To simplify the exposition and provide a closed solution to the problem we assume that

$$
f\left(r t_{i} ; a_{i}\right)=\left(r t_{i}\right)^{\beta} a_{i}^{1-\beta}
$$

The function that determines the output of the worker has to be interpreted as follows. Entrepreneurs perform two functions, formulate strategies and manage the team of people who have to implement the strategy and perform the operational activities. Higher quality of strategic decisions improves the productivity of all team members, and of any other assets of the group, in an indivisible way (scale economies). This effect is captured by the function $g(r)$, increasing in the quality of the entrepreneurial input $r$. Initially the model is formulated in static terms and ignores changes in $r$ and the external effects, beyond the particular firm, that may result from the quality of the entrepreneurial decisions. One of the variables used to value the quality of the entrepreneurial decisions, in line with the Schumpeter's view of the entrepreneur's functions, is the degree of innovation that incorporate such decisions ${ }^{2}$. The function $g(r)$ could also measure differences in the absorbing capacity of existing knowledge ${ }^{3}$.

\footnotetext{
2 The effects on economic growth of technological spillovers and diffusion of innovation have been widely stressed in the economic literature; Rosemberg (1982) points out that during the industrial revolution there were a few important innovations in selected industries that later on spread around to a large number of industries. Griliches (1979), Jaffe (1986), Audretsch and Feldman (1996) quantify the effect on economic growth of R\&D expenditures in the US economy. In Romer's (1986) growth model
} 
Management of the production team requires the entrepreneur to perform coordination and motivation activities, and some times give technical support, to make sure that strategy is effectively implemented. We call these activities managerial function of the entrepreneur. The management technology takes into account that these functions are subject to decreasing returns to scale, as the entrepreneur interact individually with each team member within a limited time and within bounded rationality constraints. The elasticity parameter $\beta$ captures this technology. Output is the result of joint team production of direct workers and the entrepreneur, so that more entrepreneurial time/services allocated to a particular worker imply higher marginal productivity of the direct worker services'. The management activities of entrepreneurs are justified when markets (invisible hand) perform coordination and motivation functions with high transaction costs. This Coasian view of the entrepreneur (visible hand) and her functions in the working of the economy, are incorporated in the model through the function $f($ ) that combines services from entrepreneurs and direct workers ${ }^{4}$.

For all direct workers, the total labor services in the economy is given by

$$
\sum l_{i}=\sum g(r) f\left(r t_{i} ; a_{i}\right)
$$

firms decide how much to invest in knowledge creation and the knowledge produced costlessly diffuses to other firms in the economy.

${ }^{3}$ Schmitz (1989) explicitly introduces the entrepreneur as an economic agent that decides to use existing knowledge to produce goods or services sold to the market. In this process the entrepreneur contributes to create new knowledge that spillover to the rest of the economy, so existing knowledge increases and has a positive impact on growth.

${ }^{4}$ The existence of transaction costs of using markets to govern exchange justifies the function of entrepreneurs as agents supplying specific information and taking actions to match supply and demand in output and input markets. Coase (1937) was the first to provide a theory of the entrepreneur as an alternative to market coordination under transaction costs (see also Williamson (1985)). Kirzner's (1979) view of the entrepreneur as the agent who discovers new opportunities for trade within existing markets, implicitly assumes that final buyers and sellers face transaction costs in doing this discovery by themselves. As an specialist the entrepreneur is able to intermediate at lower transaction costs than individual consumers and producers and can use the value of reputation from being permanently in the market to solve adverse selection and moral hazard problems. In this vein, Alchian and Demsetz (1972) explain the role of the entrepreneur as an agent that specializes in monitoring the quality and quantity of inputs used in team production technologies. Limits to perfect portfolio diversification, including those coming from moral hazard, also help to explain the role of entrepreneurs as risk takers, Kilhstrom and Laffont (1979). Our model explicitly accounts for coordination (Coase) and motivation functions (Alchian and Demsetz) of the managerial entrepreneur. Risk taking and market closing are excluded. 
The total entrepreneurial time available is $T$. We assume that there are $E$ entrepreneurs and each provides one unit of time so $T=E$. For efficiency reasons we want to assign this time so that total productive labor service is maximized,

$$
\begin{aligned}
& \operatorname{Max} Q=\sum g(r) f\left(r t_{i} ; a_{i}\right) \\
& \text { Subject to } \sum t_{i} \leq T
\end{aligned}
$$

Let $\lambda$ be the Lagrange multiplier of the constraint. This multiplier gives the marginal increase in total labor services that can be obtained with an additional unit of entrepreneurial time $T$. It is straight forward to show that in the optimal solution the ratio management time $t_{i}$ and direct worker effort $a_{i}, t_{i} / a_{i}$ has to be the same for all direct workers and is given by,

$$
t_{i} / a_{i}=\left[\lambda / g(r) r^{\beta} \beta\right]^{\frac{1}{\beta-1}}
$$

Since the restriction is binding in the optimal solution, $\Sigma t_{i}=T$; defining $A=\Sigma a_{i}$ and substituting in the binding constraint, we have,

$$
t_{i} / a_{i}=T / A=\left[\lambda / g(r) r^{\beta} \beta\right]^{\frac{1}{\beta-1}}
$$

And solving for $\lambda$, the marginal productivity of entrepreneurial time at the optimal solution,

$$
\lambda=g(r) r^{\beta} \beta \cdot T_{e}^{\beta-1}
$$

Where $T e=T / A$ is the ratio between entrepreneurial and direct workers' time, or the entrepreneurial rate of the economy.

The next step is to determine the direct workers to optimally combine with the entrepreneurial time available. Suppose that the labor market provides direct workers effort at a wage $w$. The profit maximizing value of $A$ can be determined as follows. 
Substituting the optimal solution $t_{i} / a_{i}=T / A$ in the function $f()$ and taking into account that the function is linear homogeneous,

$$
Q=\sum l_{i}=\sum a_{i} \cdot g(r) f\left(r t_{i} / a_{i}, 1\right)=A \cdot g(r) f\left(r t_{i} / a_{i}, 1\right)
$$

If output $Q$ is sold in the market at price $p$, then the profit maximizing solution for $A$ is obtained from the problem,

$$
\underset{A}{\operatorname{Max}} B=p \cdot \operatorname{Ag}(r) \cdot f(r T / A, 1)-w A
$$

For the Cobb-Douglass production function proposed above, the solution to this problem is the following,

$$
\begin{aligned}
& A^{*}=T\left[p(1-\beta) \cdot g(r) \cdot r^{\beta} / w\right]^{\frac{1}{\beta}} \\
& B^{*}=[p \cdot g(r)]^{\frac{1}{\beta}} \cdot r T \beta \cdot[(1-\beta) / w]^{1-\beta} \beta
\end{aligned}
$$

Under the assumptions of the model average and marginal maximum profit per entrepreneur are the same and equal to $B^{*} / T$. In Rosen's model, differences in quality or ability of entrepreneurs relative to direct workers will imply in equilibrium a different compensation for entrepreneurs proportional to their relative ability. If $w$ is the wage of direct workers, profit per entrepreneur will then be equal to $r w$. The equilibrium wage of direct workers, $w^{*}$ will be determined by the condition that profit per entrepreneur is equal to $r w^{*}$.

$$
r w^{*}=B^{*}\left(w^{*}\right) / T
$$

Solving this equation we obtain

$$
w^{*}=p \cdot g(r) \cdot \beta^{\beta} \cdot(1-\beta)^{1-\beta}
$$

and substituting above, 


$$
B^{*}\left(w^{*}\right) / T=r \cdot p \cdot g(r) \cdot \beta^{\beta} \cdot(1-\beta)^{1-\beta}
$$

Equilibrium salary of direct workers and equilibrium profit per entrepreneur, both increase with the quality of entrepreneurial services $r$, although the elasticity of entrepreneurs' profits with respect to the quality of entrepreneurial services is $1+\mathrm{e}(\mathrm{r})$ and the elasticity of salaries is only $e(r)$, where $e(r)$ is the elasticity of $g(r)$ with respect to $\mathrm{r}$.

Substituting the expression of $w^{*}$ in [1], this implies an entrepreneurship ratio, Te, in the equilibrium solution, of

$$
T_{e}^{*}=T / A^{*}\left(w^{*}\right)=\beta /(1-\beta) r
$$

The inverse of the ratio $T_{e}$ gives the average span of control for the representative firm, that is direct workers per entrepreneur. In the equilibrium solution the span of control will be higher in economies with higher quality of entrepreneurial services $r$ and lower in economies with higher elasticity parameter $\beta$.

If the ratio of entrepreneurs is defined over total people employed, that is the share of entrepreneur input in the occupied population, $S_{e}{ }^{*}$, we have,

$$
S_{e}^{*}=T /\left(T+A^{*}\right)=\beta /(\beta+r(1-\beta))
$$

The equilibrium share of entrepreneurs in the economy is a decreasing function of the quality of entrepreneurial services $r$ and increases with the elasticity parameter $\beta$. The inverse of this ratio provides an approximation to the average size of the representative firm of the economy and consequently the model predicts that the average size of the representative firm will be higher in economies with higher quality of entrepreneurial services $r^{5}$.

\footnotetext{
${ }^{5}$ Predictions that relate span of control and size of the firm with parameter $r$ are basically the same as those obtained by Rosen in his original model. Other papers that derive equilibrium values for the number of entrepreneurs in the economy are Schmitz (1989), assuming imitation and knowledge spillovers, and Kihlstrom and Laffont (1979) based on risk aversion.
} 
Finally, we compute the output per person employed, productivity, with variables at their equilibrium values. From the optimal solution [1] and the equilibrium share of entrepreneurs, the total output $Q^{*}$ can be written as,

$$
Q^{*}=A^{*} g(r)\left(r T / A^{*}\right)^{\beta}=A^{*} g(r)[\beta /(1-\beta)]^{\beta}=\operatorname{Tg}(r) r[(1-\beta) / \beta]^{1-\beta}
$$

Therefore, output per person employed will be equal to,

$$
Q^{*} /\left(A^{*}+T\right)=\left[T /\left(A^{*}+T\right)\right] \cdot r \cdot g(r) \cdot[(1-\beta) / \beta]^{1-\beta}
$$

Given that $T /\left(T+A^{*}\right)=\beta /(\beta+r(1-\beta))$ productivity can be written as,

$$
Q^{*} /\left(A^{*}+T\right)=r \cdot g(r) \cdot \beta^{\beta} \cdot(1-\beta)^{1-\beta} /[\beta+r(1-\beta)]
$$

Output per occupied is a function of a management technology parameter $\beta$ and of the entrepreneurial quality parameter $r$. It is immediate to show that productivity is increasing with the quality parameter $r$, that is ceteris paribus, economies with higher entrepreneurial quality $r$ will have higher productivity per person employed than economies with lower entrepreneurial quality. Productivity differences come from the effect of quality in management activities and from the effect on strategic decisions, $g(r)$.

In the equilibrium solution, the share of entrepreneurs' rents over total output, $w^{*} r T / p Q^{*}$ is equal to the elasticity $\beta$. The empirical relationship between productivity and share of entrepreneurial rents across countries can be explored by looking at variations of the productivity per occupied person as a function of changes in the elasticity parameter $\beta$. The derivative of $Q^{*} /\left(A^{*}+T\right)$ with respect to $\beta$ gives,

$$
\frac{\partial\left[Q^{*} /\left(A^{*}+T\right)\right]}{\partial \beta}=\beta^{\beta}(1-\beta)^{1-\beta} r \cdot g(r)\left[\frac{\operatorname{Ln}[\beta /(1-\beta)]}{\beta+r(1-\beta)}+\frac{r-1}{[\beta+r(1-\beta)]^{2}}\right]
$$

The sign of $\operatorname{Ln} \beta /(1-\beta)$ in this equation is positive for $\beta>1 / 2$ and zero or negative otherwise; therefore within countries where share of entrepreneurs' income is higher 
than share of direct workers' income, we expect that higher share of entrepreneurs income is associated with higher productivity, since $r-1$ is non negative by assumption. On the other hand, when comparisons are made within countries whose entrepreneurs' income share is lower than that of direct workers and relatively low value of the parameter $r$, the sing of the association between productivity and share of entrepreneurial rents is expected to be negative; however the sign of the association could be reversed for sufficiently high values of $r$. The conclusion has to be that cross countries comparisons of productivity and share of entrepreneurs' income can be meaningless unless account is taken of possible differences in quality of entrepreneurial services among them.

\section{Productivity growth over time}

Quality of entrepreneurial services in a given economy can change over time. The effect of these changes in productivity growth can be evaluated from equation [4] by computing the rate of growth of output per occupied person as a function of the rate of growth in the quality parameter $r$. Define $N=T+A^{*}$ equal to the total number of entrepreneurs and direct workers. Then the log of productivity from [4] is equal to

$$
\operatorname{Ln}\left(Q^{*} / N\right)=\operatorname{Lng}(r)+\operatorname{Ln} r+\beta \operatorname{Ln} \beta+(1-\beta) \ln (1-\beta)-\operatorname{Ln}[\beta+r(1-\beta)]
$$

If the elasticity parameter remains stable over time productivity growth depends on time improvements in the quality of entrepreneurial services. The derivative of the $\log$ of productivity with respect to time is given by,

$$
q_{t}=e(r) \rho_{t}+\rho_{t}-[r(1-\beta) /(\beta+r(1-\beta))] \rho_{t}
$$

Where $q_{t}$ is the rate of growth in output per occupied person over time, $e(r)$ is the elasticity of $g(r)$ with respect to $r$ defined before, and $\rho_{t}$ is the growth rate of quality of entrepreneurial input $r$.

We recall that $\left(r(1-\beta) /(\beta+r(1-\beta))=1-S_{e}\right.$; substituting in the productivity growth equation we have, 


$$
q_{t}=e(r) \rho_{t}+S_{e} \rho_{t}
$$

The rate of growth in productivity over time is proportional to the rate of growth in quality of entrepreneurial services. Ceteris paribus, the same rate of growth in quality services will imply a higher rate of productivity growth in economies with higher share of entrepreneurs ${ }^{6}$.

Economies with higher quality of entrepreneurial services in a given moment of time will have higher productivity and larger size of average firm, lower $S_{e}$, than economies with lower quality. However, the same rate of increase in quality of entrepreneurial services over time will imply higher productivity growth in economies with smaller size of the representative firm, that is in economies with higher share of entrepreneurs. The model implies a convergence effect in productivity over time across economies that start with different quality of entrepreneurial services but have similar rate of increase in quality of these services over time.

\section{Extensions.-}

The stylized model above can be extended to account for self employed entrepreneurs that do not hire workers and dedicate a modest amount of time to manage. Therefore if total entrepreneurs $E$ include those that have employees and those that do not, we can define $\tau_{m}$ as the proportion of effective management time per entrepreneur; so that total management time of the economy is $\tau_{m} E$. The rest of time is dedicated to direct labor, so total direct labor is equal to $\left(1-\tau_{m}\right) E+A$. Substituting these new values in the equations above, and taking into account that the equilibrium conditions of equal rents from direct labor and entrepreneurship is now $B^{*} / \tau_{m} E=r w$, we obtain that in the optimal solution the equilibrium share of entrepreneurs is given by $S_{e}^{*} / \tau_{m}=E /\left(A^{*}+E\right)=S_{e}^{\prime}$, where $S_{e}^{*}$ is the equilibrium share of entrepreneurs when all of them have people employed, derived above.

Let $E=S E+T$, where $S E$ is the number of self-employed with no employees and $T$ is the number of entrepreneurs with employees. If $\tau_{m}$ was exactly equal to the proportion 
of entrepreneurs with hired employees in the total number of entrepreneurs, then in the equilibrium solution $S_{e}^{*}=T /\left(A^{*}+E\right)$.

Production involves labor together with capital. So far we focused the attention on the aggregation of direct labor services and entrepreneurial services in an efficient, output maximizing way. A generalization of the model would require an extension to account for the aggregation of inputs labor and capital. If the entrepreneur that provides managerial services is also the capitalist that supplies the needed capital, a simple generalization of the model would consist in assuming that capital $K$ is allocated to job positions in an output maximizing way, similarly as it is the case with entrepreneurial time $T$. If $k_{i}$ is the capital allocated to job position $i$, the general allocation model can be formulated as follows,

$$
\begin{aligned}
& \underset{t_{i}, k_{i}}{\operatorname{Max}} Q=\sum g(r) f\left(r t_{i} ; a_{i} ; k_{i}\right) \\
& \sum t_{i} \leq T \\
& \sum k_{i} \leq K
\end{aligned}
$$

Similar assumptions as before, in terms of properties of the production function with capital input, give comparable results for the aggregation of labor and capital in the production function of the economy. For example, if quality of strategic entrepreneurial inputs imply higher total factor productivity of labor and capital and the production function is Cobb-Douglas with constant returns to scale and elasticity of output to capital services equal to $\alpha$, then the aggregate production function will be,

$$
Y=g(r)\left[(r T)^{\beta} A^{(1-\beta)}\right]^{(1-\alpha)} K^{\alpha}
$$

Where $Y$ represents the total output with the extended inputs. The exposition above describes the optimal combination of entrepreneurial and direct labor services under a given assumption on relative prices of the two. The relative prices of labor and capital will determine the profit maximizing mix of capital and direct labor for a given number

\footnotetext{
6 The growth model proposed by Schmitz (1989) also predicts that the growth rate of output and consumption per capita will be higher in economies with larger share of entrepreneurs, although for reasons that have to do with diffusion of knowledge.
} 
of entrepreneurs. On the other hand, labor productivity growth over time will include the effect of capital deepening, per person employed, in such growth.

These main results and the extensions give support to the following proposition about the relationship between entrepreneurship variables, economic development and growth, controlling for other factors such as capital intensity per worker and/or growth of this intensity over time.

Proposition.- a) In a cross section of countries, average size of the representative firm (share of entrepreneurs) will be higher (lower) in countries with higher quality of entrepreneurial services, relative to direct labor services.

b) In a cross section of countries, output per person employed will be higher in countries with higher quality of entrepreneurial services.

c)Elasticity $\beta$ and entrepreneurial quality $r$ parameters determine both, share of entrepreneurs and output per person employed. In a cross section of countries correlations can be found between labor productivity and the average size of representative firm (share of entrepreneurs) that have to be interpreted as the result of differences in these parameters across countries.

d) Output per person employed increases over time as the quality of entrepreneurial services also increases

e) For the same rate of increase in quality of entrepreneurial services, productivity increases at a higher rate in economies with higher starting share of entrepreneurs.

Statement a) comes from $S_{e}^{*}=T /\left(T+A^{*}\right)=\beta /(\beta+r(1-\beta))$; statement b) comes directly form equation [4]. Statement c) is the direct implication of a) and b) since both variables, size of the firm and productivity, are endogenous and a function of $r$ and $\beta$. Statements d) and e) are straightforward from [5].

\section{Review of the empirical literature.-}

The literature on entrepreneurship and economic growth measures the strength and sign of the association between indicators of economic performance and measures of entrepreneurial activity. In the model outlined above, performance measures include total output, $Y$, output per person employed, $Y /(A+T)$, output growth, $\Delta Y / Y$, and 
productivity growth, $y$. Entrepreneurial related factors are, the share of entrepreneurs, $S_{e}$, and the quality of entrepreneurial services, $r$. The share of entrepreneurs, a variable used in empirical analysis as a measure of entrepreneurial activity, is in fact endogenous and has to be explained in terms of characteristics of the managerial technology, input quality and equilibrium in relative compensation of entrepreneurs with respect to direct workers.

The accumulation of human capital through education and learning by doing of workers and entrepreneurs, together with improvements in the management technology can affect the productivity growth over time. Some times the quality of entrepreneurial services has been related to other institutional conditions, for example social mobility, and to indicators of innovation capacity, such patenting or rate new firms' creation in high tech sectors.

\section{Cross-section comparison of share of entrepreneurs and per capita income}

Entrepreneurship research has investigated the relationship between income per capita of countries and their share of entrepreneurs in the population, Kuznets (1971), Acs et al (1994), Iyigun and Owen (1998), Carree et al (2002). Early studies already find a negative cross section association between income per capita and the share of entrepreneurs; Kuznets (1971). Others report an increase in this share over time parallel to the increase in income per capita, Acs et al (1994), which is interpreted within the broader trend observed in developed countries, of increasing relative importance of small business in the population of firms, Acs and Audretsch (1993), Thurik (1999). From this evidence Carree et al (2002) postulate "an equilibrium relationship between the rate of business ownership and per capita income that is $U$ shaped (...), so there is a level of economic development with a minimum ownership rate", page 275. Countries, that have business ownership rates outside the equilibrium value corresponding to their current economic development, will be penalized with lower future growth.

Our model provides further insights into the expected cross section association between share of entrepreneurs and productivity in a given moment of time. First, notice that according to the model, both variables share of entrepreneurs and productivity are endogenous and determined by the management technology and entrepreneurial service 
quality parameters. Therefore the relationship between share of entrepreneurs and productivity has to be interpreted under this circumstance (proposition c). Figure 1 plots the simulated values of share of entrepreneurs, $\mathrm{S}_{\mathrm{e}}$ and productivity, $\mathrm{Q} / \mathrm{N}$, for different values of the parameters $\beta$ and $r$. The simulated pair values of the two endogenous variables describe the $U$ shape relationship between income per capita and share of entrepreneurs documented in empirical research.

Figure 1 tells us, first, that comparisons between entrepreneurs share, $S_{e}$, and per capita income, assuming similar occupation rates across countries, only make sense controlling for differences in the quality of the entrepreneurial input. Second, all the values along a given curve represent equilibrium values across economies of different management technology but with the same quality of entrepreneurial services. Third, a country can change the position in the picture over time because of changes in the management technology, the quality of entrepreneurial services or both. Notice that higher $r$ across countries for a given $\beta$ will imply higher income per capita.

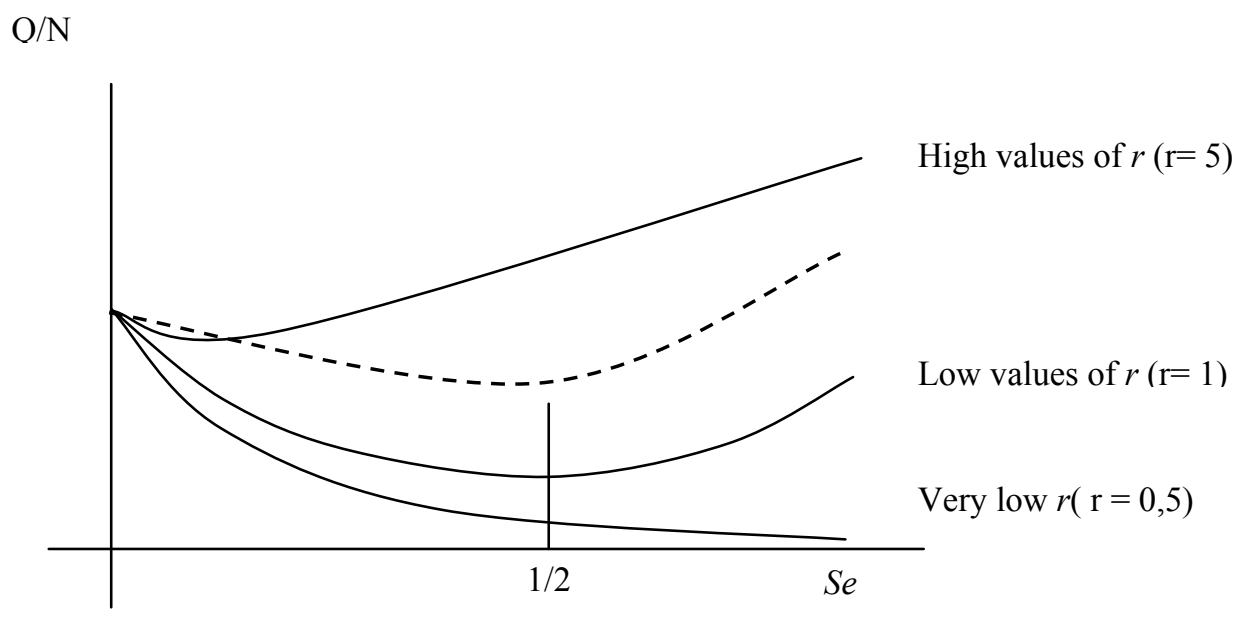

Figure 1.- Share of entrepreneurs and labor productivity for different values of parameters $r$ and $\beta$.

In countries above a minimum level of development the empirical evidence tells us that the share of entrepreneurs will be less than $1 / 2$ (less than half of the people working will be entrepreneurs). If the quality of entrepreneurs is not too different from one, a negative association is expected between entrepreneurs' share and income per capita. Countries with very low entrepreneurial quality $r$ could show a decreasing association 
between the two variables even beyond the $1 / 2$ value ${ }^{7}$. If we select a set of countries with very high value of $r$ then among these countries a positive association between entrepreneurial share and per capita income can be observed. Combining countries with very different values of $r$ in the same sample the empirically observed $U$ shaped relation between entrepreneurial share and income per capita can just pick up the heterogeneity in the values of $r$ across countries (dotted line in the Figure 1$)^{8}$.

\section{Total output and entrepreneurial capital}

Audrestsch and Keilbach (2004) model a production function with three inputs, instead of the two conventional labor and capital. They refer to this third input as "Entrepreneurship capital" and the neoclassical production function is formulated as, $Y=\alpha L^{\eta} K^{\varphi} E^{\mu}$, where $Y$ is total output, $L$ is labor, $K$ capital, $E$ is the new entrepreneurial input and $\alpha, \eta, \varphi, \mu$, are parameters of the production technology.

Audrestsch and Keilbach use the number of new firms per capita in a period of time and the number of new firms created in high tech sectors in a particular year, as proxy variables of the entrepreneurial capital of the German region for which the model is estimated. No reference is made, however, to the issue of how input services from employers and from direct workers are aggregated into the labor input $L$ and differences between quality of services from entrepreneurs and from direct workers are not made explicit.

Equation [6] represents the ex ante production function that, according to our formulation, summarizes the technological opportunities of the economy in a given period of time. The ex post actual level of production involves input mix decisions based on relative prices and technology parameters. Estimations of production functions from observed combinations of inputs and outputs across countries or across countries and over time could use equation [6] as starting point, considering number of entrepreneurs and quality of entrepreneurial services as ex ante measures of entrepreneurship capital. The profit maximizing and equilibrium conditions derived in

\footnotetext{
${ }^{7}$ We show the results with values of $\mathrm{r}$ lower than 1 for illustrative purposes.

${ }^{8}$ In fact, what Carree et al (2002) explain is share of entrepreneurs as a function of per capita GDP of the countries, that is $\mathrm{S}_{\mathrm{e}}$ would be in the vertical ax and $\mathrm{Y} / \mathrm{N}$ in the horizontal one. Their models explains share of entrepreneurs as a function of income per capita of the country and postulate a $U$ shape relationship between the two variables. This empirical relationship can also be explained by our model.
} 
the theory section alert us that observed inputs are endogenous variables decided by rational agents, and that true exogenous variables are only quality of services and technological parameters (together with interest rate as determinant of cost of capital). Most of the papers, however, including Audrestsch and Keilbach's one, treat entrepreneurial inputs as exogenous and little attention is given to the aggregation process from job positions to the whole economy.

Beyond issues of aggregation methodology and conceptual framework, the Audrestsch and Keilbach conceptual approach and empirical models would be approximately consistent with our formulation if number of new firms per capita or number of new firms in high tech sectors per capita, used as measures of entrepreneurial capital in their empirical model, are in fact considered measures of entrepreneurial quality, $r$, across German regions. That is, in our conceptual framework their empirical variables of entrepreneurial capital would be more properly considered proxy variables of the quality of entrepreneurial services than of the quantity of these services.

\section{Growth}

Van Stel et al (2005) and Wong et al (2005) study the cross section association between growth rates (of GDP and productivity) and the Total Entrepreneurial Activity rate, TEA, provided by the Global Entrepreneurship Monitor survey, controlling for other variables, in a list of 36 countries. Van Stel et al find that higher values of TEA, proportion of people in the country involved in new firms' creation, imply higher GDP growth only in the group of rich countries. If we assume that the proportion of people involved in new firms' creation is higher in countries with higher share of entrepreneurs in the population, then TEA would be positively correlated with $S_{e}$. The coefficient of TEA in these empirical analyses would then be approximately equal to the average rate of change, across countries, in the quality of entrepreneurial services $r$ over time. The fact that this coefficient is positive and significant only for developed countries and marginally negative in developing countries would indicate that the quality of the entrepreneurial input is improving over time but only in more developed countries.

Wong et al (2005) use alternative measures of entrepreneurial quality as determinants of differences in growth rates across countries, but they only find a positive association between productivity growth and number of patents relative to the GDP, an explanatory 
variable that under our framework would resemble more to the quality than to the quantity of entrepreneurial input.

\section{Empirical analysis.-}

The theoretical prediction more suitable to empirical analysis is summarized in equation [5] that gives productivity growth as a function of the proportion of entrepreneurs and of the rate of growth in quality of entrepreneurial services. Measures of quality of entrepreneurial services, beyond innovation measures such as R\&D intensity, number of patents or new products sold to the market, are difficult to obtain. Moreover these variables are proxy of quality in strategic decisions but do not capture the effects on productivity growth of better management and internal organization of firms. The empirical strategy we follow in this paper is to write productivity growth as a linear function of share of entrepreneurs at the beginning of the period; the estimated coefficient of this explanatory variable gives an estimation of the implicit annual cumulative rate of growth in the quality of the entrepreneurial services in the sample of countries.

\section{Data}

Data on variables such as productivity, share of entrepreneurs and capital stock, this one for a reduced sample of countries, are obtained from official OECD statistics on country members in the period 1970 to 2002.

The dependent variable is the annual rate of productivity growth of each country, annual rate of growth of GDP of the country per occupied person. The growth rate in productivity per person employed between period 1 and period $1+m$ is computed as $\left((Y / N)_{1+m} /(Y / N)_{1}\right)^{1 / m}-1$. The variable $S_{e}$, share of entrepreneurs, is estimated from data on labor markets of the OECD (OCDE. Labor Market and Social Issues, Quarterly Labor Force Statistics: 1965-2003). That is,

$$
S_{e}=\frac{\text { Total Labor Force- Employees -Unemployment }}{\text { Total Labor Force-Unemployment }}
$$


Some countries differ in the way labor statistics are reported: Belgium, Czech Republic, Denmark, Japan, Korea, New Zealand, Poland and Slovak Republic report figures on Civilian Labor Force instead of Total Labor Force; Switzerland and USA publish Employment Total Non Farm Private Isic B to P instead of Employees-Total; and France and New Zealand report Unemployment-Registered instead of UnemploymentTotal. Unfortunately, the population of entrepreneurs is not separated into those self employed with no hired employees and those with hired employees. Therefore we are forced to consider the total number of entrepreneurs in the country, without controlling for differences in the composition of entrepreneurial services across countries, except the control provided by the countries' fixed effects.

The labor productivity $Y / N$ for each country and time period is obtained from OECD statistics, OECD National Accounts and Historical Statistics, National Accounts I, Comparative Tables Based on Exchange Rates and Based on PPPs, GDP at the Price Levels and Exchange Rates of 1995: 1970-2002,

$$
Y / N=\frac{G D P(P P P s, \text { price levels \& exchange rates 1995) }}{\text { Total Labor Force- Unemployment }}
$$

where PPPs means Purchasing Power Parity.

The stock of capital for each country and year is obtained also from the OECD statistics and transformed into PPP values of year 1995. OECD, National Accounts and Historical Statistics, Flows and Stocks of Fixed Capital, Total, Net Stock: 1970-1997.

The country and year data used in the study together with descriptive statistics on productivity, productivity growth, entrepreneurial shares, capital ratios and growth rates in capital per person employed, are presented in Tables 1, 2, 3, 4 and 5 respectively. Tables show averages for selected five years periods and for each individual OECD country for which data are available. In the bottom of the Table we also show averages, standard deviation and coefficient of variation (standard deviation / average), for each variable across countries and for every time period. In the years 1970-1984 productivity data are available for as much as 15 countries and after 1995 we have data for all 23 
countries. Data on capital ratios are available for a very limited set of countries, nine, and a shorter period of time, up to 1997.

Values of variables across countries and over time show substantial variation. The fact that the list of countries with data available changes over time also complicates the analysis. In any case, we observe a clear divergence in productivity growth rates across countries in the period 1994-1998 and no clear trend in the evolution of the coefficient of variation in productivity growth rates over time. Countries also differ in share of entrepreneurs, Table 2, although here the cross-country average and dispersion values are relatively stable over time. If any, from the eighties, we observe a trend in convergence of shares across countries, as the standard deviation of share values slightly decreases over time. Entrepreneurial shares of the USA from the nineties show exceptionally low values, which would deserve further analysis. Robustness tests in the model estimation will try to account for possible inconsistencies in the data. Crosscountry dispersion is also high in productivity levels, Table 3, and cross country labor productivity differences seem to increase over time. However, notice that dispersion (standard deviation of individual countries' productivity values) tends to be higher when the number of countries we have data from is also higher so the increasing trend in productivity differences may just reflect an increasing number of countries over time.

Labor productivity can increase over time because of capital deepening or because improvements over time in total factor productivity. Equation [5] could be extended to allow for the effect in productivity growth of higher ratio of capital per occupied person over time. However data on capital stock is available only for a reduced number of countries and for this reason equation [5] will be estimated for the full sample of countries substituting growth in capital/labor ratio by other control variables. Next the model will be estimated for the reduced sample of countries including capital to labor ratios as explanatory variables, for robustness purposes.

\section{Empirical model}

The empirical counterpart of equation [5] is formulated as follows,

$$
y_{i t}=b_{0}+b_{1} \cdot \text { Time }+b_{2} S_{e i t-1}+b_{3}(Y / N)_{i t-1}+\sum d_{i} D_{i}+\varepsilon_{i t}
$$


The dependent variable $y_{i t}$ is the annual rate of labor productivity growth (Table 1). The explanatory variables that come directly from equation [5] are Time, a trend variable that counts the number of time periods, years, in the sample, and $S_{\text {eit- }}$, the share of entrepreneurs of country $i$ at the end of period $t-1$. The other ones, GDP per person employed in country $i$ at the beginning of the period, $(Y / N)_{i t-1}$, and country dummies $D_{i}$ are included as control variables. For the reduced sample of countries with data on capital stock the explanatory will include the ratio of capital stock per occupied person and the growth of the ratio over time.

In an unconditioned growth model parameters $b_{0}$ and $b_{1}$ provide estimates of determinants of productivity growth different from those due to more effective management functions of entrepreneurs captured by $b_{2} S_{\text {eit-1 }}$. The estimated value of $b_{2}$ gives the average differential increase in improvement in quality of entrepreneurial services, $\rho_{t}$. The conditioned growth models include as additional explanatory variables the beginning of the period productivity level and the country specific individual effects. The parameter $b_{3}$ captures cross country heterogeneity that is related to the current level of labor productivity, for example productive specialization, level of technological development, capital intensity and so on. Broadly, the lagged productivity level captures the catching up effect of less developed countries with respect to more developed ones, and for this reason the estimated coefficient of $b_{3}$ is expected to be negative.

Country dummy variables control for time invariant unobserved country idiosyncratic effects that can be correlated with the rest of explanatory variables, some of them, for example differences in number of working hours, differences in the proportion of self employed with no hired employees, propensity to save, possibly correlated with permanent differences across countries in the capital to labor ratio $K / N$ (for which data are available only for a few number of countries).

\section{Estimation of the model}

The results of estimating model [7] for the larger sample of countries are presented in Table 6. We show estimations from alternative sets of explanatory variables and for 
alternative periods of measurement of productivity growth. The first three columns refer to estimations where the dependent variable is the one year productivity growth; in column one the explanatory variables are a constant, the time trend and the share of entrepreneurs. In column two we add as explanatory variable the productivity level at the beginning of the period. Column three presents the results of the full model controlling also for country fixed effects (country dummy variables whose estimated coefficients are not reported). The last two columns show the regression results from the full model using as dependent variable five years ahead annual cumulative rate of productivity growth, with overlapping and without it respectively.

In all estimations the coefficient of the variable $S_{e}$ is positive and statistically significant, although the actual estimated value changes depending on the model specification and productivity growth variable. The range of estimated coefficients of the share of entrepreneurs variable goes from $3 \%$ to $15 \%$. The estimated average growth in the quality of entrepreneurial services implicit in our data for the large sample of OECD countries can be quite significant, taking into account that for the whole period the average annual growth rate in labor productivity is around $2 \%$. In the first part of Table 6 , the addition of explanatory variables, conditioned productivity growth model, increases the $\mathrm{R}^{2}$ of the regression, from 0.07 up to 0.21 (in all cases the increment is statistically significant). In the second part of the Table, when the dependent variable is average cumulative five years annual growth the $\mathrm{R}^{2}$ of the model is much higher, 0.59 and 0.51 ; in one case, overlapping five years periods, the low DW statistic shows evidence of high autocorrelation in the residuals.

In the full model estimation, third column, the coefficient of the time trend is positive and statistically significant but the estimated value implies a time trend in the annual growth rate of $0.11 \%$ per year. The coefficient of the start of the period productivity level is negative and statistically significant, as expected. Conditioned productivity growth models also increase the estimated value of the constant which gives the productivity growth when all the explanatory variables are equal to zero (with country dummies the constant gives the growth rate of the country whose dummy variable is omitted, Australia in our case). 
Columns one and two of Table 7 present the results of estimating model [7] in two time periods, 1980-2002 and 1990-2002. Column three shows the results for the entire time period but with countries with homogeneous labor statistics variables data. Column four to six presents the results for the set of countries for which data on growth in the capital to labor ratio is available. The purpose of this table is to provide robustness evidence for the results of Table 6. Time periods 1980-2002 and 1990-2002 are selected because they correspond to time period for which, according to Tables 1 to 3 , the panel data is more balanced as the number of countries for which data are available is larger. The results of the estimation using data from the period 1980-2002, are in line with those obtained with the full sample. However, model estimates with data from the period 1990-2002, with observations from practically all OECD countries, show a substantial increment in $\mathrm{R}^{2}$ and in the absolute values of all the estimated parameters. During the nineties productivity growth in OECD countries is highly conditioned, in an inverse way, to the starting level of productivity of the country 9 .

The evidence from columns three to six of Table 7 confirms that the main results are robust to data heterogeneity and to the inclusion of the growth rate in capital to labor ratio among the explanatory variables. The estimated coefficients of the share of entrepreneurs are between 0.14 and 0.20 , compared with the reference value of 0.15 of Table 6. Moreover, the estimated coefficient of the capital to labor growth rate in the last column of the table is around 0.43 , a reasonable result since it implies a share of capital rents in total production of $43 \%$ in line with other growth studies for OECD countries $^{10}$.

\section{Discussion and Conclusion.-}

Strong empirical evidence on entrepreneurship and economic growth is lacking, as well as theoretical models that give detailed account on why and how entrepreneurial activity

\footnotetext{
${ }^{9}$ All the results are confirmed when in each time interval the model is estimated with data only from the 14 countries for which data are available in all years since 1970 to 2002. The unconditioned growth model for the period 1990-2002 (all countries) gives an estimate of the growth rate $\rho$ equal to $4 \%$, statistically significant but lower than the $6 \%$ of Table 7 for the whole period. The conditioned growth model increases the goodness of fit of the model and the estimated values of the parameters.

${ }^{10}$ We have estimated a cross section model where labor productivity of the countries in the sample has been regressed as a function of the share of entrepreneurs and its squared (controlling for time and country effects), as suggested by Figure 1. The coefficients of the two explanatory variables are statistically significant and positive for $\mathrm{S}_{\mathrm{e}}$ and negative for $\mathrm{S}_{\mathrm{e}}^{2}$. Therefore the predicted U-shape association between productivity and share of entrepreneurs is also confirmed by our data.
} 
is often considered synonymous of prosperity and growth. Existing models, such as Schmitz (1989), relate entrepreneurship and growth through spill over from innovation decisions of entrepreneurs, while the model presented in this paper focuses in the efficient aggregation of input services from entrepreneurs, more able people, and from direct workers. The theory predicts that countries with higher entrepreneurial abilities will have higher productivity and larger firms than countries with lower abilities. However the theory also predicts that the same growth rate in quality of these services will imply higher productivity growth in countries with firms of smaller size (large share of entrepreneurs). This convergence effect of entrepreneurship in cross country productivity differences over time is new in the growth literature.

The robust empirical evidence on the positive association between next period productivity growth of a country and the share of entrepreneurs in the country at the beginning of the period, within a conditioned model of productivity growth, provided in this paper, is also new in the empirical literature on economic growth: The estimated coefficient of the share of entrepreneurs' variable in the unconditioned growth model and the full sample of data is $6.01 \%$, first column of Table 6 , and goes up to $15.33 \%$ in a fully conditioned one.

For the sample mean values of share of entrepreneurs, $S_{e}$, equal to 0.17 , and of the Time trend, 16, the predicted growth rate in productivity from the unconditioned model is $0.0131-0.0002 \times 16+0.0601 \times 0.17=2,01 \%$, very close to the actual sample average productivity growth. Out of this growth rate, the contribution from improvement in quality of entrepreneurial services and consequent improvement in managerial efficiency is $50.83 \%(0.0601 \times 0.17 / 0.02)$. This contribution comes from an estimated increase in quality of entrepreneurial services, estimated value of $\rho$, equal to $6.01 \%$, three times the rate of growth in average labor productivity. In the remaining $49,17 \%$ there may still be other contributions of improvements in quality of entrepreneurial services through the effect in better strategic decisions, but this effect can not be separated from the rest of productivity growth factors ${ }^{11}$.

\footnotetext{
11 The average annual rate of growth in the capital to labour ratio, $k$, in the sample data is $1.73 \%$. Assuming that the growth rate and the elasticity parameter $\alpha=0.44$ are similar to those of the whole sample of countries the contribution of capital intensity growth to productivity growth would be $0.76 \%$ $(0.44 \times 1.73)$.
} 
In a productivity growth model controlling only for the level of productivity in the beginning of each time period, the estimated value of $\rho$ decreases to $3.05 \%$. But it increases again to $15.33 \%$ when we control for productivity level and for country fixed effects, columns two and three of Table 6. In the model with five years cumulative average annual productivity growth as dependent variable, non overlapping periods, the estimated coefficient of $S_{e}$ is $8.21 \%$. In conditioned productivity growth models the estimate of the rate of improvement in quality of entrepreneurial inputs varies according to specifications and measurement of variables but with country specific effects it is always higher than in the unconditioned case. In the worst scenario, with estimated $\rho=3.05 \%$, the contribution of improvement in quality of entrepreneurial services to productivity growth has a lower bound of 0.52 percentage points, that is over $25 \%$ of average productivity growth of $2 \%$. In the most favorable of $\rho=15.33 \%$, the contribution would go up to $2.55 \%$, more than one hundred per cent of observed average productivity growth, that is the net contribution of other factors would be negative.

Differential quality growth in entrepreneurial services affects differently the rate of productivity growth of the countries depending on their entrepreneurial base, which in our model is endogenously determined from characteristics of the managerial technology and equilibrium with free entry conditions. Therefore countries with larger starting base of entrepreneurs in the economy show higher rate of productivity growth over time because the increase in quality of the entrepreneurial input affects a larger fraction of employed persons than in countries with small share of entrepreneurs. The gain in efficiency of entrepreneurs translates into higher productivity levels for the whole population of workers.

The paper models the number of entrepreneurs of an economy as an equilibrium solution determined by technical conditions, such as the parameters of the production and managerial technology, human capital (quality) of entrepreneurs relative to that of direct workers, and by economic conditions, quality adjusted compensation across employment opportunities under the assumption of free entry conditions to be an entrepreneur. Carree et al (2002) discusses factors that can explain differences in the share of entrepreneurs across countries and changes of this share over time, but they do not mention possible differences in the management technology. Moreover, their interpretation of the $U$ shaped relationship between share of entrepreneurs and per capita income of the country is quite different from the explanation derived from our 
model. In fact our model explains the empirical regularity of a negative association between income per capita and share of entrepreneurs by the fact that the two observable variables vary with quality of entrepreneurial services in an opposite way, increasing in the case of income per capita and decreasing in the case of share of entrepreneurs. Therefore no casual relationship can be attributed to such association.

To explain the dynamics of the management technology that determines the evolution of share of entrepreneurs over time would be an interesting line of future research, as well as determinants of differences in quality of entrepreneurial services across countries and over time. Differences in entrepreneurial abilities across people within countries will explain dispersion of firms' sizes within the country. The scale economies effects of quality in strategic decisions imply more than proportional effects of differences in ability in size differences of the respective firms. Therefore dispersion in sizes of firms within countries is expected to be a relevant variable to explain productivity and growth.

Future research should also extend the results to situations where liquidity constraints can limit the access to be an entrepreneur, when the entrepreneur is also the capitalist. In this situation entrepreneurs will manage both direct labor and capital and the model of optimal allocation of entrepreneurial time will have to determine the allocation of this time in the two inputs. On the other hand, data on number and share of entrepreneurs across countries is highly incomplete and elaborated with different criteria among them. Moreover, we only have data on capital inputs for a limited time period and for a limited set of countries, so labor productivity growth had to be modeled without controlling for growth in the capital per employed person of the countries in the sample. Finally, our data do not distinguish between entrepreneurs with and without salaried employees. The fact that the main conclusions from the estimated models (in terms of the importance of improvements in quality of entrepreneurial services to productivity growth) are robust to longer or shorter time estimation periods and to estimations from the reduced sample with capital data, suggests that the rest of the control variables avoid potential biases in the estimated coefficients.

Future work should confirm the results of the paper using more complete databases and contributing to solve some puzzling results, as for example the particularly high 
estimated value of the rate of improvement in quality of entrepreneurial services in the nineties, a period of shake out with a generalized spread of the information technologies. The effort is worthwhile considering the little we know about entrepreneurship and economic growth, the importance of entrepreneurship in economic policy actions and the, we believe, important insights obtained in this paper. 
TABLE 1: Productivity Growth $y_{i t}$. (1 year)

\begin{tabular}{|c|c|c|c|c|c|c|c|c|}
\hline & & $70-74$ & $75-79$ & $80-84$ & $85-89$ & $90-94$ & $95-99$ & $00-03$ \\
\hline AUS & Australia & 0.0099 & 0.0219 & 0.0162 & 0.0037 & 0.0197 & 0.0226 & 0.0078 \\
\hline AUT & Austria & 0.0472 & 0.0249 & 0.0034 & 0.0211 & 0.0039 & 0.0224 & 0.0119 \\
\hline BEL & Belgium $\left(^{*}\right)$ & --- & --- & --- & --- & --- & --- & 0.0118 \\
\hline CAN & Canada & 0.0178 & 0.0048 & 0.0097 & 0.0094 & 0.0101 & 0.0160 & 0.0149 \\
\hline CZE & Czech Republic $\left(^{*}\right)$ & --- & --- & -- & --- & 0.0101 & 0.0241 & 0.0262 \\
\hline DNK & Denmark $\left(^{*}\right)$ & -- & -- & -- & -- & -- & 0.0163 & 0.0203 \\
\hline FIN & Finlandia & 0.0385 & 0.0210 & 0.0194 & 0.0317 & 0.0236 & 0.0217 & 0.0176 \\
\hline FRA & France $\left(^{* *}\right)$ & 0.0371 & 0.0254 & 0.0193 & 0.0265 & 0.0122 & 0.0109 & 0.0057 \\
\hline DEU & Germany & 0.0320 & 0.0322 & 0.0082 & 0.0147 & -0.0196 & 0.0152 & 0.0132 \\
\hline HUN & Hungary & --- & -- & --- & -- & 0.0557 & 0.0296 & 0.0361 \\
\hline ITA & Italy & 0.0401 & 0.0254 & 0.0136 & 0.0270 & 0.0209 & 0.0142 & 0.0011 \\
\hline JPN & Japan $\left(^{*}\right)$ & 0.0424 & 0.0350 & 0.0195 & 0.0346 & 0.0109 & 0.0120 & 0.0182 \\
\hline KOR & Korea $\left({ }^{*}\right)$ & --- & --- & --- & --- & 0.0487 & 0.0438 & 0.0315 \\
\hline NZL & New Zealand $\left({ }^{*}\right)\left({ }^{* *}\right)$ & 0.0322 & -0.0219 & 0.0291 & -0.0180 & 0.0071 & 0.0086 & 0.0112 \\
\hline NOR & Norway & 0.0415 & 0.0235 & 0.0257 & 0.0174 & 0.0353 & 0.0176 & 0.0147 \\
\hline POL & Poland & --- & -- & --- & -- & 0.0699 & 0.0493 & 0.0389 \\
\hline PRT & Portugal & --- & --- & --- & 0.0401 & 0.0244 & 0.0113 & 0.0076 \\
\hline SVK & Slovak Republic $\left(^{*}\right)$ & --- & --- & --- & --- & -- & 0.0424 & 0.0349 \\
\hline ESP & Spain & 0.0516 & 0.0252 & 0.0330 & 0.0174 & 0.0255 & 0.0005 & -0.0040 \\
\hline SWE & Sweden & 0.0190 & 0.0043 & 0.0142 & 0.0187 & 0.0266 & 0.0247 & 0.0097 \\
\hline $\mathrm{CHE}$ & Switzerland $\left({ }^{* * *}\right)$ & -- & 0.0113 & 0.0046 & 0.0023 & -0.0070 & 0.0082 & 0.0033 \\
\hline GBR & United Kingdom & 0.0169 & 0.0193 & 0.0180 & 0.0169 & 0.0211 & 0.0149 & 0.0187 \\
\hline USA & United States $\left({ }^{* * *}\right)$ & 0.0124 & 0.0115 & 0.0108 & 0.0140 & 0.0129 & 0.0222 & 0.0123 \\
\hline \multicolumn{2}{|c|}{ No. of Countries } & 14 & 15 & 15 & 16 & 20 & 22 & 23 \\
\hline \multicolumn{2}{|c|}{ Average } & 0.0313 & 0.0176 & 0.0163 & 0.0174 & 0.0206 & 0.0204 & 0.0158 \\
\hline \multicolumn{2}{|c|}{ Standard Deviation } & 0.0136 & 0.0141 & 0.0085 & 0.0140 & 0.0206 & 0.0121 & 0.0113 \\
\hline \multicolumn{2}{|c|}{ Coefficient of Variation } & 0.4352 & 0.8032 & 0.5232 & 0.8094 & 0.9980 & 0.5922 & 0.7153 \\
\hline
\end{tabular}

(*) Civilian Labor Force instead of Total Labor Force

(**) Unemployment-Registered instead of Unemployment-Total

(***) Employees-Employment Total Non Farm Private Isic B to P instead of Employees-Total; 
TABLE 2: Entrepreneurial shares Se

\begin{tabular}{|c|c|c|c|c|c|c|c|c|}
\hline & & $70-74$ & $75-79$ & $80-84$ & $85-89$ & $90-94$ & $95-99$ & $00-03$ \\
\hline AUS & Australia & --- & 0.1660 & 0.1666 & 0.1665 & 0.1680 & 0.1579 & 0.1428 \\
\hline AUT & Austria & 0.1562 & 0.0882 & 0.1204 & 0.1493 & 0.1410 & 0.1456 & 0.1396 \\
\hline BEL & Belgium $\left(^{*}\right)$ & --- & --- & --- & --- & --- & 0.1647 & 0.1545 \\
\hline CAN & Canada & 0.1159 & 0.1256 & 0.1400 & 0.1453 & 0.1552 & 0.1698 & 0.1583 \\
\hline CZE & Czech Republic $\left(^{*}\right)$ & --- & --- & --- & --- & 0.1328 & 0.1449 & 0.1596 \\
\hline DNK & Denmark $\left(^{*}\right)$ & --- & --- & --- & --- & --- & 0.1050 & 0.0983 \\
\hline FIN & Finlandia & 0.2252 & 0.1967 & 0.1783 & 0.1656 & 0.1710 & 0.1616 & 0.1419 \\
\hline FRA & France $\left({ }^{* *}\right)$ & 0.2291 & 0.1977 & 0.1792 & 0.1629 & 0.1213 & 0.1062 & 0.0957 \\
\hline DEU & Germany & 0.1739 & 0.1588 & 0.1337 & 0.1137 & 0.1022 & 0.1072 & 0.1111 \\
\hline HUN & Hungary & --- & --- & --- & --- & 0.1993 & 0.1767 & 0.1522 \\
\hline ITA & Italy & 0.3351 & 0.3081 & 0.3109 & 0.3154 & 0.3026 & 0.3041 & 0.2905 \\
\hline JPN & Japan $\left(^{*}\right)$ & 0.3254 & 0.2964 & 0.2718 & 0.2483 & 0.2055 & 0.1786 & 0.1613 \\
\hline KOR & Korea $\left(^{*}\right)$ & --- & --- & --- & 0.4083 & 0.3782 & 0.3725 & 0.3613 \\
\hline NZL & New Zealand $\left({ }^{*}\right)\left({ }^{* *}\right)$ & 0.1320 & 0.1482 & 0.1343 & 0.1908 & 0.2115 & 0.2080 & 0.1988 \\
\hline NOR & Norway & 0.1788 & 0.1595 & 0.1492 & 0.1343 & 0.1218 & 0.0899 & 0.0804 \\
\hline POL & Poland & --- & --- & --- & --- & 0.3105 & 0.2866 & 0.2770 \\
\hline PRT & Portugal & --- & --- & 0.3365 & 0.3255 & 0.2927 & 0.2941 & 0.2792 \\
\hline SVK & Slovak Republic $\left(^{*}\right)$ & --- & --- & --- & --- & 0.0630 & 0.0681 & 0.0884 \\
\hline ESP & Spain & 0.3517 & 0.3207 & 0.3201 & 0.3042 & 0.2699 & 0.2431 & 0.1955 \\
\hline SWE & Sweden & 0.0980 & 0.0817 & 0.0790 & 0.0770 & 0.0944 & 0.1081 & 0.1003 \\
\hline $\mathrm{CHE}$ & Switzerland $\left({ }^{* * *}\right)$ & --- & --- & --- & --- & 0.1056 & 0.1276 & 0.1302 \\
\hline GBR & United Kingdom & 0.0926 & 0.0883 & 0.1073 & 0.1417 & 0.1525 & 0.1388 & 0.1253 \\
\hline USA & United States $\left({ }^{* * *}\right)$ & 0.1189 & 0.1148 & 0.1111 & 0.1012 & 0.0829 & 0.0581 & 0.0456 \\
\hline \multicolumn{2}{|c|}{ No. of Countries } & 13 & 14 & 15 & 16 & 21 & 23 & 23 \\
\hline \multicolumn{2}{|c|}{ Average } & 0.1948 & 0.1751 & 0.1826 & 0.1969 & 0.1801 & 0.1703 & 0.1603 \\
\hline \multicolumn{2}{|c|}{ Standard Deviation } & 0.0919 & 0.0812 & 0.0847 & 0.0948 & 0.0861 & 0.0811 & 0.0768 \\
\hline \multicolumn{2}{|c|}{ Coefficient of Variation } & 0.4718 & 0.4641 & 0.4637 & 0.4816 & 0.4782 & 0.4759 & 0.4792 \\
\hline
\end{tabular}

(*) Civilian Labor Force instead of Total Labor Force

(**) Unemployment-Registered instead of Unemployment-Total

(***) Employees-Employment Total Non Farm Private Isic B to P instead of Employees-Total; 
TABLE 3: Labor Productivity Y/N

(Dollars PPPs, prices levels and exchange rates 1995)

\begin{tabular}{|c|c|c|c|c|c|c|c|c|}
\hline & & $70-74$ & $75-79$ & $80-84$ & $85-89$ & $90-94$ & $95-99$ & $00-03$ \\
\hline AUS & Australia & $33,668.1$ & $36,376.8$ & $39,052.4$ & $41,565.3$ & $43,671.5$ & $48,733.4$ & $51,807.1$ \\
\hline AUT & Austria & $33,736.1$ & $39,678.3$ & $42,152.2$ & $44,598.2$ & $48,432.8$ & $50,880.2$ & $55,023.2$ \\
\hline BEL & Belgium $\left({ }^{*}\right)$ & --- & --- & --- & --- & --- & $60,319.4$ & $62,028.0$ \\
\hline CAN & Canada & $39,796.2$ & $41,354.9$ & $42,069.5$ & $45,053.5$ & $46,438.1$ & $50,104.3$ & $54,004.5$ \\
\hline CZE & Czech Republic $\left(^{*}\right)$ & --- & --- & --- & --- & $23,980.2$ & $26,288.4$ & $28,846.3$ \\
\hline DNK & Denmark $\left(^{*}\right)$ & --- & --- & --- & --- & --- & $46,559.3$ & $50,172.5$ \\
\hline FIN & Finlandia & $26,542.3$ & $29,485.7$ & $33,072.7$ & $37,875.6$ & $41,841.3$ & $48,368.6$ & $52,282.5$ \\
\hline FRA & France $\left(^{* *}\right)$ & $33,801.2$ & $38,635.1$ & $43,269.1$ & $48,296.8$ & $53,439.8$ & $56,176.5$ & $58,241.0$ \\
\hline DEU & Germany & $38,557.6$ & $45,146.3$ & $47,716.8$ & $51,798.3$ & $47,759.4$ & $49,812.7$ & $52,992.7$ \\
\hline HUN & Hungary & --- & --- & --- & --- & $23,246.6$ & $26,923.2$ & $30,457.5$ \\
\hline ITA & Italy & $34,150.6$ & $39,051.1$ & $43,563.9$ & $48,421.5$ & $53,360.9$ & $59,913.0$ & $61,466.5$ \\
\hline JPN & Japan $\left(^{*}\right)$ & $24,653.0$ & $28,987.2$ & $32,916.3$ & $37,930.8$ & $42,473.6$ & $44,954.3$ & $47,455.7$ \\
\hline KOR & Korea $\left(^{*}\right)$ & --- & --- & --- & $18,838.3$ & $21,908.9$ & $27,124.9$ & $31,546.1$ \\
\hline NZL & New Zealand $\left({ }^{*}\right)\left(^{* *}\right)$ & $37,901.9$ & $36,578.6$ & $38,071.3$ & $36,340.8$ & $37,207.6$ & $38,438.0$ & $40,739.8$ \\
\hline NOR & Norway & $28,444.0$ & $31,815.1$ & $35,687.8$ & $39,632.7$ & $45,809.6$ & $51,976.0$ & $55,354.1$ \\
\hline POL & Poland & --- & --- & --- & --- & $17,462.1$ & $20,542.2$ & $25,957.2$ \\
\hline PRT & Portugal & --- & --- & $21,576.7$ & $24,187.2$ & $28,375.6$ & $31,204.3$ & $31,819.5$ \\
\hline SVK & Slovak Republic $\left(^{*}\right)$ & --- & --- & --- & --- & $19,478.7$ & $21,952.6$ & $25,606.7$ \\
\hline ESP & Spain & $28,129.9$ & $31,964.2$ & $36,958.7$ & $41,858.7$ & $45,834.7$ & $48,934.8$ & $48,149.1$ \\
\hline SWE & Sweden & $32,307.7$ & $33,661.5$ & $35,223.7$ & $39,173.4$ & $42,588.9$ & $49,523.2$ & $53,003.2$ \\
\hline $\mathrm{CHE}$ & Switzerland $\left(^{* * *}\right)$ & --- & $44,819.3$ & $46,219.1$ & $46,852.8$ & $45,339.3$ & $46,482.5$ & $48,066.2$ \\
\hline GBR & United Kingdom & $29,120.9$ & $31,575.6$ & $34,399.3$ & $38,443.2$ & $41,040.2$ & $45,422.9$ & $48,123.0$ \\
\hline USA & United States $\left({ }^{* * *}\right)$ & $44,616.1$ & $46,733.1$ & $48,294.1$ & $52,351.9$ & $56,011.3$ & $60,952.8$ & $64,853.5$ \\
\hline \multicolumn{2}{|c|}{ No. of Countries } & 14 & 15 & 16 & 17 & 21 & 23 & 23 \\
\hline \multicolumn{2}{|c|}{ Average } & $33,244.7$ & $37,057.5$ & $38,765.2$ & $40,777.6$ & $39,319.1$ & $43,982.1$ & $46,869.4$ \\
\hline \multicolumn{2}{|c|}{ Standard Deviation } & $5,612.7$ & $5,789.5$ & $6,827.2$ & $8,817.9$ & $11,921.0$ & $12,377.2$ & $12,083.3$ \\
\hline \multicolumn{2}{|c|}{ Coefficient of Variation } & 0.1688 & 0.1562 & 0.1761 & 0.2162 & 0.3032 & 0.2814 & 0.2578 \\
\hline
\end{tabular}

(*) Civilian Labor Force instead of Total Labor Force

(**) Unemployment-Registered instead of Unemployment-Total

(***) Employees-Employment Total Non Farm Private Isic B to P instead of Employees-Total; 
TABLE 4: Capital per occupied person K/N

(Dollars PPPs, prices levels and exchange rates 1995)

\begin{tabular}{|c|c|c|c|c|c|c|c|}
\hline & & $70-74$ & $75-79$ & $80-84$ & $85-89$ & $90-94$ & $95-97$ \\
\hline AUS & Australia & $82,404.2$ & $98,278.7$ & $110,053.3$ & $116,963.4$ & $116,823.1$ & $116,182.0$ \\
\hline CAN & Canada & $61,325.2$ & $64,640.4$ & $65,498.0$ & $61,327.8$ & $60,976.6$ & $59,865.2$ \\
\hline FIN & Finland & $73,852.1$ & $92,547.3$ & $103,726.7$ & $119,247.2$ & $138,094.9$ & $136,959.7$ \\
\hline FRA & France $\left({ }^{* *}\right)$ & $62,477.3$ & $84,362.5$ & $102,072.3$ & $108,989.8$ & $120,406.8$ & $124,458.8$ \\
\hline DEU & Germany & $91,602.9$ & $110,509.6$ & $129,186.4$ & $136,029.3$ & $123,942.9$ & -- \\
\hline ITA & Italy & --- & --- & $155,922.0$ & $162,053.7$ & $178,026.7$ & $192,552.8$ \\
\hline NOR & Norway & --- & $100,701.4$ & $105,071.7$ & $126,408.6$ & $140,314.4$ & --- \\
\hline GBR & United Kingdom & $84,352.8$ & $99,642.5$ & $104,583.4$ & $107,014.8$ & $106,832.0$ & --- \\
\hline USA & United States $\left({ }^{* * *}\right)$ & $96,081.9$ & $111,203.5$ & $120,395.6$ & $119,198.4$ & $121,263.7$ & $125,447.6$ \\
\hline \multicolumn{2}{|c|}{ No. of Countries } & 7 & 8 & 9 & 9 & 9 & 6 \\
\hline \multicolumn{2}{|c|}{ Average } & $78,870.9$ & $95,235.7$ & $110,723.3$ & $117,470.3$ & $122,964.6$ & $125,911.0$ \\
\hline \multicolumn{2}{|c|}{ Standard Deviation } & $13,556.3$ & $15,157.9$ & $24,281.1$ & $26,813.3$ & $31,049.7$ & $42,478.8$ \\
\hline \multicolumn{2}{|c|}{ Coefficient of Variation } & 0.1719 & 0.1592 & 0.2193 & 0.2283 & 0.2525 & 0.3374 \\
\hline
\end{tabular}

(*) Civilian Labor Force instead of Total Labor Force

(**) Unemployment-Registered instead of Unemployment-Total

(***) Employees-Employment Total Non Farm Private Isic B to P instead of Employees-Total;

\begin{tabular}{|c|c|c|c|c|c|c|c|}
\hline \multicolumn{8}{|c|}{$\begin{array}{l}\text { TABLE 5: Growth rate in Capital per occupied person } k_{i t}(1 \text { year) } \\
\text { (Dollars PPPs, prices levels and exchange rates } 1995)\end{array}$} \\
\hline & & $70-74$ & $75-79$ & $80-84$ & $85-89$ & $90-94$ & $95-97$ \\
\hline AUS & Australia & 0.0551 & 0.0245 & 0.0217 & -0.0009 & 0.0089 & -0.0271 \\
\hline CAN & Canada & 0.0193 & 0.0037 & 0.0020 & -0.0146 & 0.0030 & -0.0111 \\
\hline FIN & Finland & 0.0748 & 0.0287 & 0.0205 & 0.0378 & 0.0191 & -0.0199 \\
\hline FRA & France $\left({ }^{* *}\right)$ & 0.0866 & 0.0435 & 0.0279 & 0.0135 & 0.0181 & 0.0069 \\
\hline DEU & Germany & 0.0433 & 0.0424 & 0.0205 & 0.0075 & -0.0225 & --- \\
\hline ITA & Italy & --- & --- & 0.0218 & 0.0080 & 0.0294 & -0.0007 \\
\hline NOR & Norway & -- & 0.0150 & 0.0158 & 0.0451 & 0.0152 & -- \\
\hline GBR & United Kingdom & 0.1413 & 0.0094 & -0.0062 & 0.0147 & -0.0245 & -- \\
\hline USA & United States $\left({ }^{* * \star}\right)$ & 0.0433 & 0.0246 & -0.0012 & 0.0055 & 0.0050 & 0.0123 \\
\hline \multicolumn{2}{|c|}{ No. of Countries } & 7 & 8 & 9 & 9 & 9 & 6 \\
\hline \multicolumn{2}{|c|}{ Average } & 0.0663 & 0.0240 & 0.0137 & 0.0130 & 0.0057 & -0.0066 \\
\hline \multicolumn{2}{|c|}{ Standard Deviation } & 0.0398 & 0.0144 & 0.0121 & 0.0184 & 0.0184 & 0.0155 \\
\hline \multicolumn{2}{|c|}{ Coefficient of Variation } & 0.6003 & 0.6002 & 0.8899 & 1.4191 & 3.2079 & -2.3369 \\
\hline
\end{tabular}

(*) Civilian Labor Force instead of Total Labor Force

(**) Unemployment-Registered instead of Unemployment-Total

(***) Employees-Employment Total Non Farm Private Isic B to P instead of Employees-Total; 


\begin{tabular}{|c|c|c|c|c|c|}
\hline \multicolumn{6}{|c|}{$\begin{array}{l}\text { TABLE 6: Results of the estimation of model [7]. } \\
b_{0}+b_{1} \cdot \text { Time }+b_{2} S e_{i t-1}+b_{3}(Y / N)_{i t-1}+\sum d_{i} D_{i}+\varepsilon_{i t}\end{array}$} \\
\hline \multirow{2}{*}{$\begin{array}{c}\text { Coefficients } \\
\text { (Explanatory } \\
\text { variables) }\end{array}$} & \multicolumn{3}{|c|}{1 year productivity growth } & \multicolumn{2}{|c|}{5 year productivity growth } \\
\hline & 1 & 2 & 3 & $\begin{array}{c}\text { With } \\
\text { overlapping }\end{array}$ & $\begin{array}{c}\text { Without } \\
\left.\text { overlapping( }{ }^{1}\right)\end{array}$ \\
\hline \multirow[t]{2}{*}{$\mathrm{b}_{0}$ (Interception) } & $0.0131^{* \star *}$ & $0.0429^{* * *}$ & $0.0452^{* *}$ & $0.0594^{* * *}$ & $0.0591^{* * *}$ \\
\hline & $(0.0030)$ & $(0.0051)$ & $(0.0169)$ & $(0.0078)$ & $(0.0173)$ \\
\hline \multirow[t]{2}{*}{$b_{1}$ (Time) } & $-0.0002^{* *}$ & 3.12E-05 & $0.0011^{* * *}$ & $0.0013^{* * *}$ & $0.0067^{* * *}$ \\
\hline & $(0.0001)$ & $(0.0001)$ & $(0.0003)$ & $(0.0001)$ & $(0.0016)$ \\
\hline \multirow[t]{2}{*}{$b_{2}\left(\mathrm{Se}_{\mathrm{it}-1}\right)$} & $0.0601^{* \star *}$ & $0.0305^{* *}$ & $0.1533^{* * *}$ & $0.0856^{* * *}$ & $0.0821^{* *}$ \\
\hline & $(0.0109)$ & $(0.0112)$ & $(0.0378)$ & $(0.0174)$ & $(0.0411)$ \\
\hline \multirow[t]{2}{*}{$b_{3}\left([Y / N]_{i t-1}\right)$} & --- & $-7.11 \mathrm{E}-07^{\star * *}$ & $-1.76 \mathrm{E}-06^{\star * *}$ & $-1.97 \mathrm{E}-06^{* * *}$ & $-2.02 \mathrm{E}-06^{\star \star *}$ \\
\hline & & (1.02E-07) & $(4.27 \mathrm{E}-07)$ & $(1.91 \mathrm{E}-07)$ & $(4.35 \mathrm{E}-07)$ \\
\hline Country Dummies & NO & NO & YES & YES & YES \\
\hline Adjusted $\mathrm{R}^{2}$ & 0.0688 & 0.1520 & 0.2137 & 0.5949 & 0.5140 \\
\hline$F$ value & $19.105^{\star \star *}$ & $30.267^{* \star *}$ & $6.3255^{\star * *}$ & $25.600^{\star * *}$ & $4.8346^{\star * *}$ \\
\hline Durbin-Watson & 1.6169 & 1.7032 & 1.7961 & 0.4621 & 2.1998 \\
\hline No. observations & 491 & 491 & 491 & 403 & 88 \\
\hline
\end{tabular}

Standard error in brackets.

$*, * *, * *$, significant at 10,5 and $1 \%$, respectively

(') Periods 1972-76, 1977-81, 1982-86, 1987-91,1992-96, 1997-2002

\begin{tabular}{|c|c|c|c|c|c|c|}
\hline$y_{i t}=b_{0}+b$ & $\begin{array}{r}\text { TABLE } \\
\text { Time }+b_{2} S\end{array}$ & $\begin{array}{l}\text { 7: Robustn } \\
e_{i t-1}+b_{3}(Y /\end{array}$ & $\begin{array}{l}\text { ess of resul } \\
N)_{i t-1}+b_{4} k\end{array}$ & $\begin{array}{l}\text { ts of Table } \\
+b_{5}(K / 1\end{array}$ & ${ }_{i t-1}+\sum$ & $D_{i}+\varepsilon_{i t}$ \\
\hline Coefficients & All col & untries & Sample $\left({ }^{1}\right)$ & Count & s with Cap & al Data \\
\hline (Explanatory & 1980-2002 & 1990-2002 & $1970-2002$ & & $1970-1997$ & \\
\hline & 1 & 2 & 3 & 4 & 5 & 6 \\
\hline$b_{0}$ (Interception) & $0.0626^{\star * *}$ & $0.2715^{\star * *}$ & $0.0337^{*}$ & 0.0485 & -0.0238 & 0.0071 \\
\hline & $(0.0222)$ & $(0.0388)$ & $(0.0195)$ & (0.0391) & $(0.1559)$ & $(0.0362)$ \\
\hline $\mathrm{b}_{1}$ (Time) & $0.0016^{* * *}$ & $0.0057^{* * *}$ & $0.0009^{* *}$ & $0.0011^{*}$ & $0.0006^{* *}$ & $0.0018^{* * *}$ \\
\hline & $(0.0004)$ & $(0.0008)$ & $(0.0004)$ & $(0.0006)$ & $(0.0003)$ & $(0.0005)$ \\
\hline$b_{2}\left(\mathrm{Se}_{\mathrm{it}-1}\right)$ & $0.1811^{* * *}$ & $0.3481^{* * *}$ & $0.1998^{* * *}$ & 0.1408 & $0.1477^{*}$ & $0.1965^{* *}$ \\
\hline & $(0.0503)$ & $(0.0977)$ & $(0.0505)$ & $(0.0942)$ & $(0.0765)$ & $(0.0940)$ \\
\hline$b_{3}\left([Y / N]_{i t-1}\right)$ & $-2.16 \mathrm{E}-06^{\star * *}$ & $-7.30 \mathrm{E}-06^{* * *}$ & $-1.56 \mathrm{E}-06^{\star * *}$ & $-1.85 \mathrm{E}-06^{* *}$ & --- & $-3.55 \mathrm{E}-06^{* * *}$ \\
\hline & $(5.20 \mathrm{E}-07)$ & (8.37E-07) & (4.88E-07) & $(8.87 \mathrm{E}-07)$ & & $(1.01 \mathrm{E}-06)$ \\
\hline $\mathrm{b}_{4}\left(\mathrm{k}_{\mathrm{it}}\right)$ & --- & --- & --- & --- & $0.3883^{\star * *}$ & $0.4337^{* * *}$ \\
\hline & & & & & $(0.0590)$ & $(0.0597)$ \\
\hline$b_{5}\left([K / N]_{i t-1}\right)$ & --- & --- & --- & --- & --- & $7.54 \mathrm{E}-07^{* * *}$ \\
\hline & & & & & & $(2.51 \mathrm{E}-07)$ \\
\hline Country Dummies & YES & YES & YES & YES & YES & YES \\
\hline Adjusted $\mathrm{R}^{2}$ & 0.2111 & 0.4059 & 0.1647 & 0.0900 & 0.2495 & 0.2939 \\
\hline$F$ value & $5.0780^{\star * *}$ & $7.5598^{* * *}$ & $5.3519^{* * *}$ & $2.7080^{* *}$ & $6.7435^{\star * *}$ & $7.0827^{\star \star \star *}$ \\
\hline Durbin-Watson & 1.8134 & 1.6851 & 1.8233 & 1.8475 & 1.7333 & 1.5763 \\
\hline No. observations & 382 & 241 & 332 & 191 & 191 & 191 \\
\hline
\end{tabular}

Standard error in brackets.

$*, * *, * * *$, significant at 10,5 and $1 \%$, respectively

(') Only countries with homogeneous data: Belgium, Czech Republic, Denmark, France, Japan, Korea, New Zealand,

Slovak Republic, Switzerland and USA data excluded. Notes $(*),(* *)$ and $(* * *)$ in Tables 1-5. 


\section{Bibliography.-}

Acs, Z.J. and D.B. Audretsch. (1990). Innovation and Small Firms. Cambridge, MA: MIT Press.

Acs, Z. J., D. Audretsch and D. Evans .(1994). The Determinants of Variations in the Self- Employed Rates Across Countries and over Time. Mimeo.

Acs, Z. J. and D. Storey. (2004). "Introduction: Entrepreneurship and Economic Development”. Regional Studies. Vol. 38, pp. 871-877.

Alchiam, A. and H. Demsetz. (1972). "Production, Information and Economic organization”. American Economic Review. Vol. 62, pp. 777-795.

Audrestsch, D. B., and M.P. Feldman. (1996). "R\&D Spillovers and the Geography of Innovation and production". American Economic Review. 86(3), pp. 630-640.

Audretsch, D. B. and M. Keilbach. (2004). "Entrepreneurship Capital and Economic Performance". Regional Studies. Vol. 38, p. 949-959.

Baumol, W. J. (1968). "Entrepreneurship in Economic Theory". American Economic Review. Vol. 58, No. 2, pp. 64-71.

Baumol, W J. (2004). "Entrepreneurial Enterprises, Large Established Firms and Other Components of the Free-Market Growth Machine". Small Business Economics. Vol. 23, pp. 9-21.

Callejón, M. and A. Segarra. (1999). "Business Dynamics and Efficiency in Industries and Regions: The Case of Spain”. Small Business Economics. Vol. 1, pp. 253-271.

Carree, M., A. van Stel, R. Thurik and S. Wennekers. (2002). "Economic Development and Business Ownership: An Analysis Using Data of 23 OECD Countries in the Period 1976-1996”. Small Business Economics. Vol. 19, pp. 271-290. 
Coase, R. (1937). “The Nature of the Firm”. Economica. 4: pp. 386-405.

Evans, D. and B. Jovanovic (1998). "An Estimated Model of Entrepreneurial Choice under Liquidity Constraints", Journal of Political Economy. Vol. 97, pp 808-827.

Griliches, Z. (1979). "Issues in Assessing the Contribution of R\&D to Productivity Growth”. The Bell Journal of Economics. Spring Vol. 10, pp.92-116.

Iyigun, M. and A. Owen. (1998). "Risk, Entrepreneurship and Capital Accumulation", American Economic Review, Papers and Proceedings, 88, pp. 454-457.

Jaffe, A. (1986). "Technological Opportunity and Spillovers of R\&D: Evidence from Firms' Patents, Profits and Market Value”, American Economic Review, 76, pp. 9841001 .

Kihlstrom, R. and J. Laffont (1979). "A General Equilibrium Entrepreneurial Theory of the Firm", Journal of Political Economy, 87, pp. 719-748.

Knight, F. (1921). Risk, Uncertainty and Profit. Harper and Row, N. Y.

Kirzner, I. (1979). Perception, Opportunity and Profit. The University of Chicago Press. Chicago.

Kuznets, S. (1971). Economic Growth of the Nations, Total Output and Production Structure, Harvard Uni. Press, Cambridge, MA.

Lucas, R.(1978). "On the Size Distribution of Firms “, Bell Journal of Economic. 9, pp. 508-523.

Nickel, S., P. Nicolistas and N. Dryden .(1997). "What Makes Firms Perform Well?" European Economic Review, 41, pp. 783-796.

Romer, P. (1986). "Increasing Returns and Long-Run Growth". Journal of Political Economy. Vol. 94, pp. 1002-1037. 
Rosen, S. (1982). "Authority, Control, and the Distribution of Earnings". The Bell Journal of Economics. Vol. 13, pp. 311-323.

Rosemberg, N.(1982). Inside the Black Box. Technology and Economics, Cambridge Uni. Press N. Y.

Schmitz, J.(1989). "Imitation, Entrepreneurship and Long-Run Growth", Journal of Political Economy. Vol. 97, pp. 721-739.

Schumpeter, J. A. (1934). The Theory of Economic Development: an Inquiry into Profits, Capital, Credit, Interest, and the Business Cycle. Transaction Books. London. 1983.

van Stel, A., M. Carree and R.Thurik. (2005). "The Effect of Entrepreneurial Activity on National Economic Growth”. Small Business Economics. Vol. 24, pp. 311-321.

Thurik, A. (1999). "Entrepreneurship, Industrial Transformation and Growth", in G. Libecap (ed.) The Sources of Entrepreneurial Activity: Vol. 11, Advances in the Study of Entrepreneurship, Innovation and Economic Growth, JAI Press, pp. 29-65.

Williamson, O. (1985). The Economic Institutions of Capitalism. New York. Free press.

Wong, K. P., Y. P. Ho and E. Autio. (2005). "Entrepreneurship, Innovation and Economic Growth: Evidence from GEM Data", Small Business Economics. Vol. 24, pp. 335-350. 


\section{Edicions / Issues:}

95/1 Productividad del trabajo, eficiencia e hipótesis de convergencia en la industria textil-confección europea

Jordi López Sintas

95/2 El tamaño de la empresa y la remuneración de los máximos directivos Pedro Ortín Ángel

95/3 Multiple-Sourcing and Specific Investments

Miguel A. García-Cestona

96/1 La estructura interna de puestos y salarios en la jerarquía empresarial Pedro Ortín Ángel

96/2 Efficient Privatization Under Incomplete Contracts Miguel A. García-Cestona

Vicente Salas-Fumás

96/3 Institutional Imprinting, Global Cultural Models, and Patterns of OrganizationalLearning: Evidence from Firms in the Middle-Range Countries Mauro F. Guillén (The Wharton School, University of Pennsylvania)

96/4 The relationship between firm size and innovation activity: a double decision approach

Ester Martínez-Ros (Universitat Autònoma de Barcelona)

José M. Labeaga (UNED \& Universitat Pompeu Fabra)

96/5 An Approach to Asset-Liability Risk Control Through Asset-Liability Securities Joan Montllor i Serrats

María-Antonia Tarrazón Rodón

97/1 Protección de los administradores ante el mercado de capitales: evidencia empírica en España

Rafael Crespí i Cladera

97/2 Determinants of Ownership Structure: A Panel Data Approach to the Spanish Case Rafael Crespí i Cladera

97/3 The Spanish Law of Suspension of Payments: An Economic Analysis From

Empirical Evidence

Esteban van Hemmen Almazor

98/1 Board Turnover and Firm Performance in Spanish Companies

Carles Gispert i Pellicer

98/2 Libre competencia frente a regulación en la distribución de medicamentos:

teoría y evidencia empírica para el caso español

Eva Jansson

98/3 Firm's Current Performance and Innovative Behavior Are the Main Determinants of Salaries in Small-Medium Enterprises

Jordi López Sintas y Ester Martínez Ros 
98/5 Modelo de previsión y análisis del equilibrio financiero en la empresa Antonio Amorós Mestres

99/1 Avaluació dinàmica de la productivitat dels hospitals i la seva descomposició en canvi tecnològic i canvi en eficiència tècnica

Magda Solà

99/2 Block Transfers: Implications for the Governance of Spanish Corporations

Rafael Crespí, and Carles Gispert

99/3 The Asymmetry of IBEX-35 Returns With TAR Models

M. a Dolores Márquez, César Villazón

99/4 Sources and Implications of Asymmetric Competition: An Empirical Study Pilar López Belbeze

99/5 El aprendizaje en los acuerdos de colaboración interempresarial Josep Rialp i Criado

00/1 The Cost of Ownership in the Governance of Interfirm Collaborations Josep Rialp i Criado, i Vicente Salas Fumás

00/2 Reasignación de recursos y resolución de contratos en el sistema concursal español Stefan van Hemmen Alamazor

00/3 A Dynamic Analysis of Intrafirm Diffusion: The ATMs Lucio Fuentelsaz, Jaime Gómez, Yolanda Polo

00/4 La Elección de los Socios: Razones para Cooperar con Centros de Investigación y con Proveedores y Clientes

Cristina Bayona, Teresa García, Emilio Huerta

00/5 Inefficient Banks or Inefficient Assets?

Emili Tortosa-Ausina

01/1 Collaboration Strategies and Technological Innovation: A Contractual Perspective of the Relationship Between Firms and Technological Centers

Alex Rialp, Josep Rialp, Lluís Santamaria

01/2 Modelo para la Identificación de Grupos Estratégicos Basado en el Análisis Envolvente de Datos: Aplicación al Sector Bancario Español

Diego Prior, Jordi Surroca

01/3 Seniority-Based Pay: Is It Used As a Motivation Device?

Alberto Bayo-Moriones

01/4 Calidad de Servicio en la Enseñanza Universitaria: Desarrollo y Validación de una Escala de Medida.

Joan-Lluís Capelleras, José M. ${ }^{a}$ Veciana 
01/5 Enfoque estructural vs. recursos y capacidades: un estudio empírico de los factores clave de éxito de las agencias de viajes en España.

Fabiola López-Marín, José M. ${ }^{a}$ Veciana

01/6 Opción de Responsabilidad Limitada y Opción de Abandonar: Una Integración para el Análisis del Coste de Capita.

Neus Orgaz

01/7 Un Modelo de Predicción de la Insolvencia Empresarial Aplicado al Sector Textil y Confección de Barcelona (1994-1997).

Antonio Somoza López

01/8 La Gestión del Conocimiento en Pequeñas Empresas de Tecnología de la Información: Una Investigación Exploratoria.

Laura E. Zapata Cantú

01/9 Marco Institucional Formal de Creación de Empresas en Catalunya: Oferta y

Demanda de Servicios de Apoyo

David Urbano y José María Veciana.

02/1 Access as a Motivational Device: Implications for Human Resource Management. Pablo Arocena, Mikel Villanueva

02/2 Efficiency and Quality in Local Government. The Case of Spanish Local Authorities M.T. Balaguer, D. Prior, J.M. Vela

02/3 Single Period Markowitz Portfolio Selection, Performance Gauging and Duality: A variation on Luenberger's Shortage Function

Walter Briec, Kristiaan Kerstens, Jean Baptiste Lesourd

02/4 Innovación tecnológica y resultado exportador: un análisis empírico aplicado al sector textil-confección español

Rossano Eusebio, Àlex Rialp Criado

02/5 Caracterización de las empresas que colaboran con centros tecnológicos

Lluís Santamaria, Miguel Ángel García Cestona, Josep Rialp

02/6 Restricción de crédito bancario en economías emergentes: el caso de la PYME en México

Esteban van Hemmen Almazor

02/7 La revelación de información obligatoria y voluntaria (activos intangibles) en las entidades de crédito. Factores determinantes.

Gonzalo Rodríguez Pérez

02/8 Measuring Sustained Superior Performance at the Firm Level Emili Grifell - Tatjé, Pilar Marquès - Gou

02/9 Governance Mechanisms in Spanish Financial Intermediaries Rafel Crespi, Miguel A. García-Cestona, Vicente Salas

02/10 Endeudamiento y ciclos políticos presupuestarios: el caso de los ayuntamientos catalanes

Pedro Escudero Fernández, Diego Prior Jiménez 
02/11 The phenomenon of international new ventures, global start-ups, and bornglobals: what do we know after a decade (1993-2002) of exhaustive scientific inquiry? Àlex Rialp-Criado, Josep Rialp-Criado, Gary A. Knight

03/1 A methodology to measure shareholder value orientation and shareholder value creation aimed at providing a research basis to investigate the link between both magnitudes

Stephan Hecking

03/2 Assessing the structural change of strategic mobility. Determinants under hypercompetitive environments

José Ángel Zúñiga Vicente, José David Vicente Lorente

03/3 Internal promotion versus external recruitment: evidence in industrial plants Alberto Bayo-Moriones, Pedro Ortín-Ángel

03/4 El empresario digital como determinante del éxito de las empresas puramente digitales: un estudio empírico

Christian Serarols, José M. ${ }^{a}$ Veciana

03/5 La solvencia financiera del asegurador de vida y su relación con el coste de capital Jordi Celma Sanz

03/6 Proceso del desarrollo exportador de las empresas industriales españolas que participan en un consorcio de exportación: un estudio de caso

Piedad Cristina Martínez Carazo

03/7 Utilidad de una Medida de la Eficiencia en la Generación de Ventas para

Predicción del Resultado

María Cristina Abad Navarro

03/8 Evaluación de fondos de inversión garantizados por medio de portfolio insurance Sílvia Bou Ysàs

03/9 Aplicación del DEA en el Análisis de Beneficios en un Sistema Integrado Verticalmente Hacia Adelante

Héctor Ruiz Soria

04/1 Regulación de la Distribución Eléctrica en España: Análisis Económico de una Década, 1987-1997

Leticia Blázquez Gómez; Emili Grifell-Tatjé

04/2 The Barcelonnettes: an Example of Network-Entrepreneurs in XIX Century Mexico. An Explanation Based on a Theory of Bounded Rational Choice with Social Embeddedness.

Gonzalo Castañeda

04/3 Estructura de propiedad en las grandes sociedades anónimas por acciones. Evidencia empírica española en el contexto internacional

Rabel Crespí; Eva Jansson

05/1 IFRS Adoption in Europe: The Case of Germany.

Soledad Moya, Jordi Perramon, Anselm Constans 
05/2 Efficiency and environmental regulation: a 'complex situation' Andrés J. Picazo-Tadeo, Diego Prior

05/3 Financial Development, Labor and Market Regulations and Growth Raquel Fonseca, Natalia Utrero

06/1 Entrepreneurship, Management Services and Economic Growth Vicente Salas Fumás, J. Javier Sánchez Asín 